\title{
ARCHITEKTŪRA PARODOJE (LIETUVOS ATVEJIS)
}

\author{
Asta Visminaité丶 $\dot{e}^{1}$ Julija Reklaitè ${ }^{2}$ \\ ${ }^{1}$ Kultūros platforma „KultFliuksas“, Antakalnio g. 88-15, 10204 Vilnius, Lietuva \\ ${ }^{2}$ Vilniaus Gedimino technikos universitetas, Architektūros fakultetas, \\ Pylimo g. 26/Trakug. 1,01132 Vilnius, Lietuva \\ El.paštas: ${ }^{1}$ asta.visminaite@gmail.com; ${ }^{2}$ julija.reklaite@gmail.com \\ Iteikta 20101206
}

\begin{abstract}
Santrauka. Straipsnio pavadinimas atskleidžia pasirinktos temos dviprasmiškumą ir dvilypị architektūros vaidmenį: architektūra gali būti suvokiama ir kaip parodoje analizuojamas objektas ar problema (architektūros paroda), ir kaip parodą formuojantis elementas (parodos architektūra). Tekste siekiama atskleisti šio santykio dualumą, o kartu ịrodyti, kad kai kalbama apie architektūros bei jos konteksto santykị - imamos vartoti tarpdiscipliniškumo ir kolaboracijos sąvokos, tuomet santykis tarp objekto ir jo eksponavimo būdo kinta, o riba tarp to, kas yra architektūra parodoje, ir kas yra parodos architektūra - išnyksta.

Straipsnyje pristatant parodų tipus ir parodų architektūros lygmenis bei kolaboracines formas aptariamas Lietuvos parodinis kontekstas, analizuojamos šiandieninės situacijos sąlygos ir priežastys. Nagrinejjant parodų architektūros temą išskirti trys parodų tipai, tai dokumentuojančiosios, tiriančiosios ir apibendrinančiosios praktikos, kurios skiriasi analizės ir kuravimo būdais bei tikslais. Analizuojant parodų architektūros arba architektūros pristatymo būdus išskirti trys - $2 \mathrm{~d}, 3 \mathrm{~d}$ ir $4 \mathrm{~d}$ - lygmenys, kurie, be instaliavimo būdo, skiriasi žiūrovo ịtraukimo bei informacijos interpretavimo lygiu.
\end{abstract}

Reikšminiai žodžiai: architektūra kaip medija, paroda kaip laboratorija, architektūros kultūra, kismas, identitetas, parodos ir architektūros sąvoka, kolaboracija.

„Paroda: teikti, pasiūlyti;

Manifestacija: perteikti manifesta;

Ekspozicija: absoliučiai išreikšti išore -

yra juridiniai, retoriniai, politiniai ir filosofiniai terminai “

Jean-Francois Lyotard

\section{Ivadas}

Architektūros, jos formos, funkcijos ir reikšmès suvokimas medijų prisotintoje visuomeneje nuolat kinta. Iš vienos pusès - architektūra suvokiama ne tik kaip funkcijų talpykla, bet ir kaip medija; ịvaizdžio, fotogeniškumo, galios formavimo elementas ir simbolis. Iš kitos pusès - parodos sąvoka ir reikšmè taip pat kinta, iš artefaktų eksponavimo vietos ji tampa informacijos, kismo, patirties, diskusijų lauku. Straipsnio pavadinimas atskleidžia pasirinktos temos dviprasmiškumą ir dvilypị architektūros vaidmeni. Ji gali būti suvokiama ir kaip parodoje analizuojamas objektas ar problema, ir kaip parodą formuojantis elementas, todèl straipsny- je nagrinejjamos dvi temos - architektūrą pristatančios parodos ir parodų architektūra. Parodos suvokimas apskritai krypsta nuo pasyvaus rodymo link aktyviai ittraukiančio žiūrèjimo ar dalyvavimo, link ịvykio per $s e$, ji tampa svarbiu elementu formuojant ir analizuojant architektūros kultūros reiškinius, architektūros sampratos bei vaidmens visuomeneje klausimus, todèl šiems reiškiniams reikalingas atskiras dèmesys. Kaip knygos „Parodų dizainas“ (Exhibition design) įvade rašo jos autorius David Dernie „parodų dizainas yra ịvaizdžio, sukurto komunikuoti ir galingai patirčiai perteikti, sinonimas" (Dernie 2006: 6). 
Temos apie architektūros vietą ir reikšmę ekspozicijose pasirinkimą konferencijos pranešimui lèmé Lietuvoje pastaruoju metu susiklosčiusi specifinè situacija. Jau penkerius metus neturime architektūros muziejaus, o 2009 m. realizuotus Valdovu rūmus galima ironiškai suvokti kaip pastatą, kuris savaime yra eksponatas. Tais pačiais metais atsidare ir rekonstruota Nacionalinè dailès galerija, kuri iki tol buvo Revoliucijos muziejaus pastatas. Ivyko rezonansinis, tačiau architektūros pasaulyje mažai išdiskutuotas Gugenheimo-Ermitažo architektūrinis konkursas ir galimybių studija. Tema iš tiesų be galo aktuali, o jokie teoriniai tyrimai, be pavieniu architektūros ekspozicijų rengimo atvejų, nèra atliekami, tarsi ir nèra konstruktyvios kritikos ar architektūros teorijos tekstų šia tema.

Pabrèžtinas ir svarbus yra šio pranešimo konteks$\operatorname{tas}^{1}$, kuriame architektūra nèra suprantama siaurąja prasme kaip statybos amatas, ji analizuojama kaip socialinis, ekonominis, meninis reiškinys, kaip viena iš galią generuojančių kūrybinių industrijų ir svarbi kultūros dalis. Svarbu pažymèti, jog šiame pranešime architektūra iš dalies yra suprantama ir kaip mediju produktas, informaciją skleidžiantis objektas ${ }^{2}$.

Apie architektūrą dažniausiai kalbama, ji pristatoma ir analizuojama pasitelkiant ịvairias reprezentacijos formas; kaip žiūrovas priims informaciją parodoje, taip pat priklauso nuo pasirinktos reprezentacijos technikos, analizès technikos, kolekcijos sudarymo technikos (Curating Architecture... 2007). Todèl šiame tekste nagrinejjant parodų tipus kaip informacijos pateikimo formas ir parodų eksponavimo būdus, bandoma susieti architektūros ir meninių praktikų panašumus bei skirtumus ir rasti šių dviejų sričių sąlyčio taškus. Parodų tipai ir parodų eksponavimo būdai šiame straipsnyje yra sąlygiškai išskirti ir apibūdinti autorių, apibendrinus pasaulinio parodinio konteksto įžvalgas. Tekstas parengtas remiantis konferencijos pranešimu, kuriame susipynè asmeninès autorių patirtys ir teoriniai, dažniausiai užsienio pavyzdžiai, todèl tekste nèra siekiama mokslinio objektyvumo.

\section{Parodų tipai}

Žvelgiant istoriškai, žinios apie architektūrinès medžiagos kolekcionavimą ir eksponavimą siekia XVIII a. Tačiau praktiškai iki šių dienų, kalbant apie architektūros parodas, vyraujančia tendencija galima būtų laikyti dokumentuojančiąsias parodas - tai to-

\footnotetext{
${ }^{1}$ Apie eksponavimo kontekstą taip pat rašo ir Dernie, kuris teigia, kad parodos „skaitymas“ priklauso nuo konteksto ir prezentacijos.

2 Pasitelkiant skambiąją M. Mcluhano (2003) frazę „Medija yra žinute“" (Media is the message).
}

kios parodinès praktikos, kuriose pateikiami atskirų architektų ar tam tikro periodo architektūriniai darbai (personalinès, istorinès, apžvalginès parodos). Dokumentuojančiosiose parodose paprastai vyrauja konvencinis galerinès parodos formatas, t. y. medžiaga joje pateikiama šimtmečiais naudotomis vizualiomis architektūrinès raiškos priemonėmis: brèžiniais, piešiniais, nuotraukomis, modeliais. Tačiau būtent tradiciniu mediju architektūrai pristatyti naudojimas parodose sukelia daugiausiai diskusijų tarp šiuolaikinių architektūros kritikų bei kuratorių. Kaip pastebi architektūros teoretikas prof. Riklef Rambow, architektai savo vertybes ir kokybès kriterijus bando paaiškinti profesionalios architektūros aspektu, naudodami ekspertinę kalbą, kuri ne visada gali būti suprantama paprastam žiūrovui (Rambow 2004). Profesionalia architektūrine kalba pristatomi objektai parodoje dažnai eliminuoja specialaus išsilavinimo neturinčių ir architektūrinès kalbos nesuprantančių parodos lankytojų poreikius. Todèl pasaulyje lyderiaujančios, architektūros parodas rengiančios institucijos ekspozicijoje esančią informaciją siekia pateikti orientuodamosi $\mathfrak{z}$ skirtingas žinias ir išsilavinimą turintị žiūrovą.

Nors ir nepasižyminčias gausa, tačiau dokumentuojančiąsias parodas galima laikyti dominuojančiu parodų tipu Lietuvoje. Vienas iš ryškiausių tokias parodas pristatančių pavyzdžių Lietuvoje galètų būti Lietuvos architektūros muziejus, veikęs 1968-2006 m. Vilniuje (Baužienè 2009). Pastovi ekspozicija, kurioje buvo pristatomi Lietuvos architektūros istorijos periodai $1918-1940 \mathrm{~m}$. bei 1944-1990 m. (1 pav.), buvo statiška, joje eksponuojami projektų planai ir maketai, šalia eksponatų trūko išsamesnès informacijos apie objektus. Muziejus dirbo tradiciniais ir šiuolaikinio muziejų lankytojo poreikių netenkinančiais metodais, galbūt tai viena iš priežasčių, kodèl jame rengiamos parodos neturèjo didesnio rezonanso kultūriniame bei architektūriniame gyvenime ar viešajame sektoriuje.

Panašiais principais iš esmès remèsi ir naujausia Lietuvos architektūros paroda „Našlaičiai“ (2010 11 05-2011 01 09, 2 pav.), pristatanti žymių Lietuvos architektų meistrų kūrybinị palikimą Nacionalinèje dailès galerijoje. Nors ir pasitelktas gana lengvas (skaidrus) bei kokybiškas originalių brěžinių ir eskizų eksponavimo variantas, paroda iš esmès primena grafikos darbų peržiūrą ir yra suprantama labiau profesionalams; darbai ekspozicijai atrinkti subjektyviai, nesivadovaujant bendra kūrinius vienijančia koncepcija. Paroda iš esmès atitinka dokumentuojančiosios parodos tipą, nes jos tikslas - atskleisti in memoriam architektų kūrybini kelią (Reklaitè 2010).

Bene labiausiai šiuo metu architektūros bendruomenei yra aktualios tokios parodos, kuriose atveriamos 


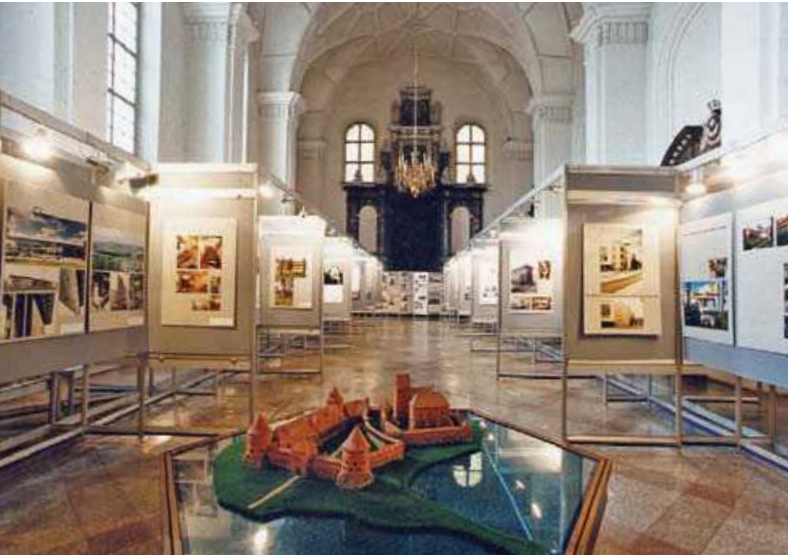

1 pav. Lietuvos architektūros muziejus, 2004 m., iš Mortos Baužienès asmeninio archyvo

Fig. 1. Lithuanian Museum of Architecture, 2004

galimybès diskutuoti apie pačią architektūros definiciją ir skirtingas jos sampratas. Tiriančiosiomis architektūros parodomis gali būti įvardijama tokia parodos strategija, kurioje iškeliamas eksperimento diskursas. Tokios parodos dažnai tampa utopinių, eksperimentinių bei erdvę naujai formuojančių architektūros formų pateikimo aikštele. Nors tokiose parodose taip pat gali būti țtraukiamas informacinis aspektas, paprastai informacija jose suponuoja platesnę diskusiją apie architektūros sampratą, kelia kritinius klausimus apie mus supančią urbanistinę aplinką. Tiriančiosios parodos yra teigiamai vertinamos ir pačių architektų, nes ne tik kvestionuoja nusistovejusias architektūros ar urbanistikos praktikas, bet ir, anot architektūros kritiko ir kuratoriaus Frederiko Migayrou, suteikia galimybę tiesioginiam architektų ryšiui su žiūrovu (vartotoju, visuomene), kartu palieka erdvę paaiškinti, kokiais principais remiamasi kūrybineje veikloje (Migayrou 2005: 115). Tiriančiosioms parodoms galètų būti priskiriamos erdvinès instaliacijos, konceptualaus meno ar šiuolaikinio meno formas naudojančios parodos, paviljonai, architektūrines ar urbanistines praktikas viešosiose erdvèse pristatančios parodos.

Lietuvos architektūros pristatymo kontekste tiriančiosios parodos pavyzdžiu iš dalies galima būtų laikyti Lietuvos architektų sąjungos įrengtus mobilius stendus Lukiškių aikštes prieigose (3 pav.). Kaip ne itin innoringa ir lanksti prezentacijos forma mobilūs stendai tarp architektūros kuratorių yra palankiai vertinami dèl to, jog jais gali būti atkreipiamas už kultūros ar architektūros institucijų ribų esančių visuomenès narių dèmesys ị erdvès formavimo klausimus. Naudojant mobilius stendus pasiekiama tokia auditorija, kuri galbūt niekados neateitų i i institucijoje pristatomą parodą.

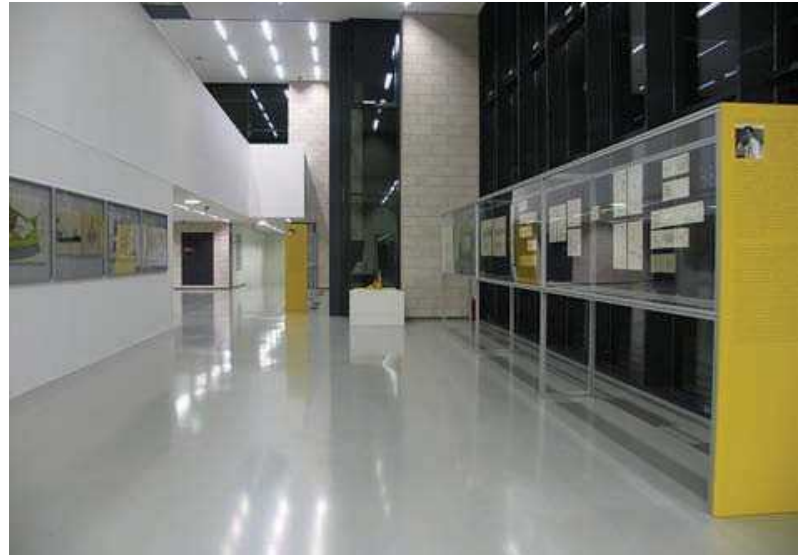

2 pav. Paroda "Našlaičiai", NDG, 2010 m., Julijos Reklaitès fotografija

Fig. 2. "Orphans", exhibition photo in National Gallery of Arts, 2010

Be to, stendo architektūra dažnai yra atvira aplinkinei erdvei, ekspozicijos žiūrovas nepraranda tiesioginio ryšio su išorine erdve, todèl taip gali būti kvestionuojami stendą supančio konteksto klausimai. Nudojant tokią parodos formą galima kalbetti apie urbanistinius procesus, atkreipti žiūrovo dèmesị ị miesto vietą, kurioje jis apžiūri ekspoziciją, tačiau, ypač naudojant tas pačias vizualines priemones, dažnai stendai gali būti painiojami su reklamine miesto tarša.

Apibendrinančiosioms parodoms gali būti priskirti didesnio masto renginiai, $\mathfrak{i}$ kuriuos įtraukiamas ne vienas kuratorius, dažnai kelių šalių architektai. Juose pristatomos pavienių architektų ar jų grupių praktikos, kurios gali būti siejamos panašios veiklos ideologijos, bendros kuratoriaus nustatytos temos. Šị tipą galima būtų iliustruoti Niujorko modernaus meno muziejuje MoMA 1932 m. vykusios parodos „Moderni architektūra: tarptautinis stilius" (Modern Architecture:

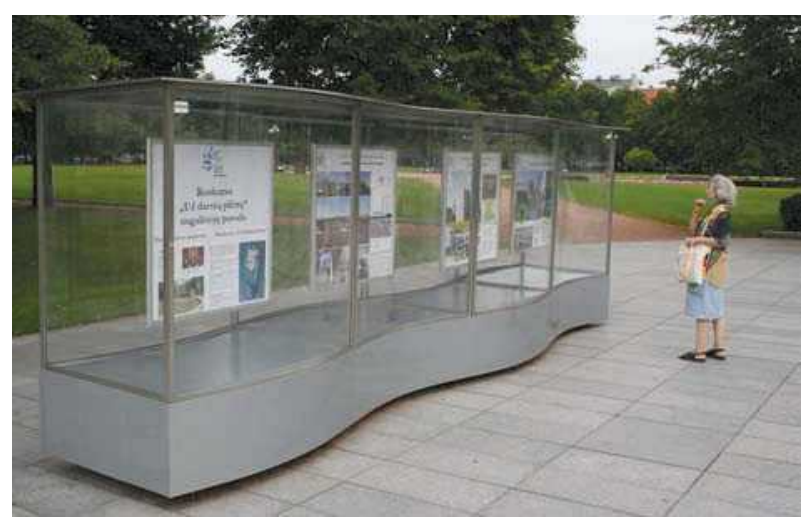

3 pav. Laikini parodiniai stendai Lukiškių aikštès prieigose Vilniuje (iš www.Intpa.lt)

Fig. 3. Temporary mounts at Lukiškès Square in Vilnius 
International Style) ar Venecijos architektūros bienalès parodų pavyzdžiais. Dèl savo didelio formato, paprastai nemažo biudžeto reflektuojančios parodos yra itin tinkamos urbanistiniams procesams ar urbanistinèms praktikoms pristatyti ir tirti kompleksiškai įtraukiant ivairius diskursus ir projektus. Deja, šio tipo parodų ar architektūriniu rezonansinių ịvykių pavyzdžių Lietuvoje rasti būtų sunku.

\section{Eksponavimo būdai}

Du vienodai svarbūs parodos komponentai yra turinys ir forma. Jos kaip reiškinio sèkmè susijusi ne tik su konceptualia informacija, kurią siekiama perteikti, bet ir su pačiais eksponavimo metodais ar parodoje rodomais objektais. Kaip teigia D. Dernie, „kuriant parodų dizainą atsižvelgiama ị dialogą tarp eksponuojamų objektų ir erdvés, kurioje jie eksponuojami; nuo to, kur ir kaip jie perteikiami, priklauso žinutes, kurią jie išreiškia, esmè“ (2006). Kalbant apie parodos eksponavimo būdus ir formas, sąlygiškai galima išskirti tris eksponavimo lygmenis: dviejų dimensijų, arba plokščią, eksponavimo būdą; trijų dimensijų - kai vyrauja tūris ir erdve; bei keturiu dimensiju - kai įtraukiama laiko dimensija, t. y. interaktyvios instaliacijos, žiūrovo patirtys ir ịvairios medijos.

Dviejų dimensijų eksponavimo būdas iš esmès atmeta architektūros kaip erdvès, socialinio mokslo ir kompleksinio meno sąvoką. Tradiciškai parodoje architektūra reprezentuojama naudojant autorinị bréžini, piešini, fotografijas, t. y. akcentuojant dvimati architektūros vaizdą, kuris neprofesionalui gali būti sunkiai suprantamas ir galiausiai vertinamas kaip plokštuminis grafikos kūrinys. Tačiau architektūra nuo kitų menų skiriasi būtent tuo, kad ji kalba apie erdvę ir tos erdvès funkciją, ji kalba apie žmogų, sociumą ir kaip objektas yra pajejgi ittraukti kitus menus. Tradicinès ir statiškos parodos vaizdavimo priemonès žiūrovą itraukia tik tiek, kiek jis pats yra suinteresuotas ir pasiruošęs tą informaciją priimti, kiek jis išsilavinęs suprasti specifinę architektūrinę „kalbą“. Dažniausiai provokacijos ir postūmio interpretuoti tokioje parodoje nesiekiama, tad diskursyvus požiūris ị architektūrą, miesto procesų analizé ar visuomenès ịtraukimas ị viešą diskusiją tokiose parodose nèra skatinami.

Šio parodos tipo pavyzdžiais Lietuvoje laikytinos etapinès , architektūros architektams“ parodos, tokios kaip „Žvilgsnis ị save“, „Vilniaus architektūra“ (4 pav.), „Doleta“ ir pan., kurios iš dalies tarsi užpildo architektūrinès informacijos trūkumą, bet yra suprantamos ir įdomios gerai kontekstą išmanančiai, siaurai profesinei bendruomenei. Labai dažnai jos yra siejamos su geriausių darbų konkursais, kuriuose komisija, na-

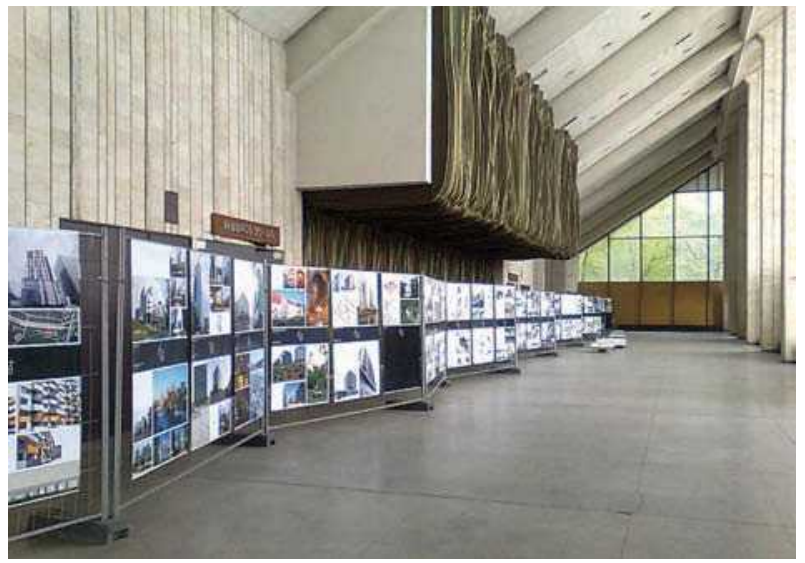

4 pav. Paroda "Vilniaus architektūra 2007-2008“ Vilniaus Koncertų ir sporto rūmuose, Astos Visminaitès fotografija

Fig. 4. Exhibition "Architecture of Vilnius 2007-2008" in Palace of Culture and Sports in Vilnius

grinèdama pateiktą medžiagą, išrenka ir viešai apdovanoja geriausius darbus, taip skatinama ir deklaruojama architektūros kokybè. Tačiau kita vertus, tokios parodos iliustruoja Vakaruose vis labiau kritikuojamą architektūros vizualumo išryškinimą ${ }^{3}$, kai architektūra tampa fotogenišku, vizualiu objektu, kai formuojamas įvaizdis, orientuojamasi ị tūrių santykius, proporcijas, pateikimo būdus ir kartu gilinamas atotrūkis tarp architektūros teorijos bei praktikos, architektūros ir kitų meno šakų.

Neatsiejama parodos dalis yra tekstas. Tekstu galima pateikti daug ir išsamios informacijos, ittraukiant ir paaiškinant ịvairius su eksponuojama architektūra susijusius aspektus. Siekiant supažindinti su informacija žiūrovą ir lygiavertiškai suteikti galimybes jam dalyvauti diskusijoje su profesionalais, tekstą architektūros parodoje siūloma pateikti skirtingais lygmenimis, t. y. dalị teksto orientuoti ị neprofesionalų žiūrovą (aprašymus, koncepcijas ir kt.), o gilesnių ir išsamesnių žinių ieškantiems žmonèms pridèti ir detalesnị tekstą, kuriame gali atsirasti specifinè terminologija. Tekstą kaip reprezentacijos formą palanku taikyti urbanistines praktikas pristatančiose parodose, kuriose svarbi vieta tenka socialiniams procesams, miesto politikai ir raidai - vien tik vizualinemis prezentacijos formomis tokiose parodose procesus atskleisti sudetinga. Lietuvoje rengiamas etapines parodas kartais lydi katalogai (pvz., parodoje „Vilniaus architektūra“ pateikiami

\footnotetext{
3 Architektūros parodų kuratorès Kristin Fereiss teigimu, „architektūros parodose visada pirmiausiai yra svarbiau ideju ir konceptų, o ne meno perteikimas. Neabejotinai didelę meninę vertę turinčius individualių architektų piešinius galima laikyti maloniu pašaliniu parodos efektu, bet jie nebūtinai savaime pateisina jų eksponavimą parodoje“ (Feireiss 2001: 8).
} 
katalogai); juose dažniausiai informacija pateikiama faktografiškai, tačiau vis dar mažai dèmesio skiriama kritiniams ar analitiniams straipsniams.

Nuo dviejų dimensijų eksponavimo būdo šiek tiek skiriasi triju dimensiju parodos, kuriose architektūra nagrinëjama kaip erdvè, eksponatams pateikti naudojami ịvairūs tūriai, maketai, žiūrovai gali suvokti ir analizuoti architektūrą kaip erdvinị reiškinị. Tokiose parodose atsiranda ir interaktyvumo lygmuo, kai lankytojas gali savo kūnu patirti erdvès dydžius, analizuoti jam lengviau suprantamas architektūros formas, nereikalaujančias specialaus išsilavinimo. Šis eksponavimo būdas daugiau skirtas ne siaurai architektūros profesionalų auditorijai, o plačiajai visuomenei. Prie tokių parodų iš dalies gali būti priskirti ir erdviniai architektūros (kaip parodos organizavimo priemonès) sprendimai, kai muziejuose ir kitose parodinėse erdvèse naudojant pertvaras, barjerus ar kitas priemones organizuojamas lankytojo maršrutas ir ekspozicijos naratyvas, kuriamas parodos ịvaizdis. Reikia pripažinti, kad tai yra niša menininkų, kuratorių ir architektų kolaboratorinèms praktikoms. Architektai šioje srityje gali dirbti drauge su kuratoriais padedami paaiškinti tekstinį, istorinį, koncepcinị parodos naratyvą erdvinèmis vizualinèmis raiškos priemonemis. Pavyzdžiui, kuriant ịvaizdị parodoje "Tylusis modernizmas" (kuratore Elona Lubyte, architektas Valdas Ozarinskas (5 pav.). Prie šio parodos tipo gali būti priskirta Audriaus Novicko kuruota paroda "Miesto žymejjimas“ (2002 m., galerijoje „ARTeritorija“, Kaunas), kurioje miesto ir architektūros sąvokas plačiąja prasme savo darbais analizavo bei interpretavo tarptautinè menininkų bei architektų grupé (Miesto žymejjimas 2005: 241), taip pat architekto Valdo Ozarinsko kuruota paroda „(Ne) lyderis“, kurioje nagrinèta architektūros sąvoka nenaudojant tiesioginių

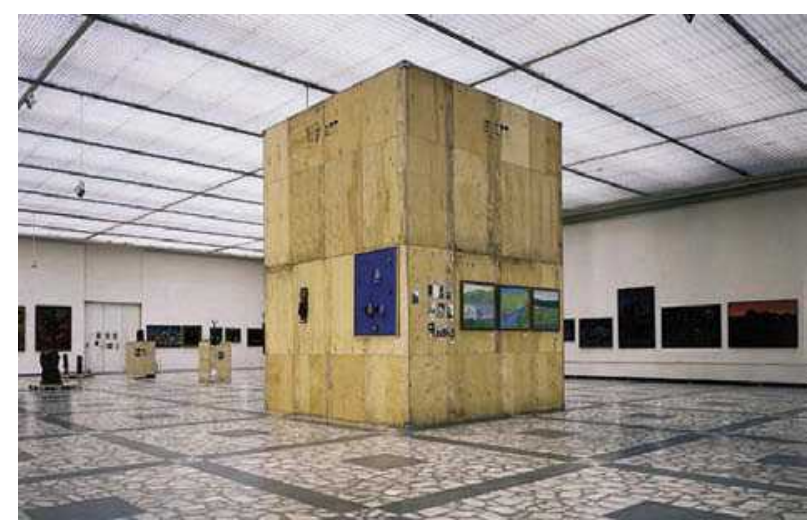

5 pav. Parodos "Tylusis modernizmas" apipavidalinimas, 1997 m. (iš www.cac.lt)

Fig. 5. Design of exhibition "Silent Modernism", 1997 architektūrinių îvaizdžių (6 pav.). Tai parodos, kuriose architektūra nagrinejjama platesne prasme, kuriamas kritinis diskursas, pristatomos idejos ir koncepcijos, o ne koncentruojamasi į dizaino ar meno objektus.

Lietuvoje architektūros sąvoką nagrinėjančių parodų arba parodų, kuriose ryškus menininkų bei architektų bendradarbiavimas, nèra daug. Nors visos stambesnès ekspozicinès institucijos turi savo architektus, tačiau dažnai jų darbas suprantamas siaurai, kai architektai nèra ittraukiami ị kolaboracines praktikas pradiniuose ekspozicijų rengimo etapuose, jų vaidmuo apsiriboja eksponatų vietos parinkimu.

Kitas eksponavimo būdas, sąlygiškai (šiuo atveju pabrèžiant laiko ir lankytojui suteikiamos patirties svarbą) pavadintas keturias dimensijas įtraukiančios parodos, yra glaudžiausiai susijęs su analize ir teorijos diskursu bei su meninèmis praktikomis. Jose naudojamos ịvairios paralelinès medijos tiek architektūros ar kitų menų sąvokoms nagrinèti, tiek auditorijai įtraukti ir provokuoti. Tai ịvairios instaliacijos ir veiksmu bei laiku (trukme) pagristos eksponavimo praktikos, kurios tampa ypač aktualizuotos, kai kalbama apie erdvés patyrimo aspektą ir ryšį su žiūrovu. Tokiose parodose sąveikauja ịvairios medijos ir jau vien savo buvimu praplečia suvokimo ribas, rengiant tokias parodas labai svarbus yra eksperimentavimo momentas. Parodų, nagrinejjančiu architektūros problemas Lietuvoje, nèra, o šiuolaikinio meno pasaulyje interaktyvių ir instaliacinių, performatyvių praktikų yra gausu.

Tradicinés parodos suvokimas bendrąja prasme yra susijęs su dviejų dimensijų medijų naudojimu turiniui pažinti, su dažniausiai dokumentuojančiu, o ne tiriamojo pobūdžio objektų pristatymu ir chronologiniu naratyvu. Tenka pripažinti, jog tradiciné paroda Lietuvoje dažniausiai yra dokumentuojanti ir plokščia.

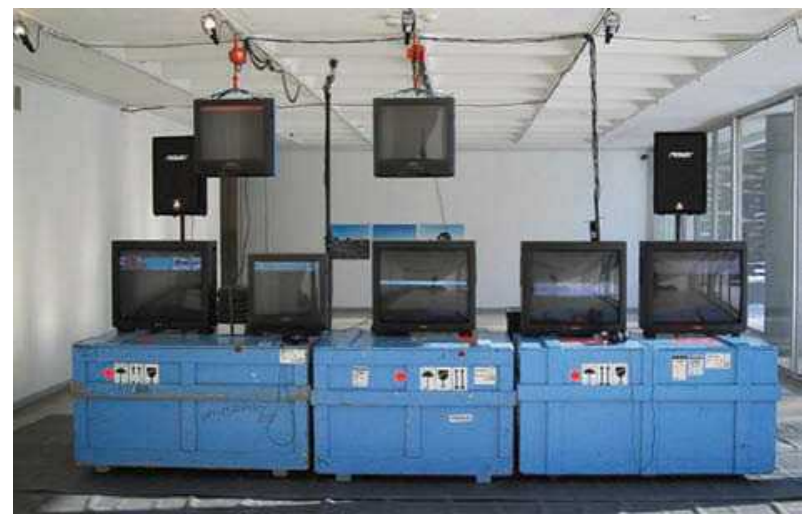

6 pav. Parodos „(Ne) lyderis" fragmentas, $2004 \mathrm{~m}$. (iš www.cac.It)

Fig. 6. Fragment of exhibition "(Not) Leader", 2004 


\section{Parodos sąvokos kaita}

Šiuolaikinių parodų praktikų kontekste tradicinè paroda yra kritikuojama, nes konvencinemis priemonėmis pateikiama medžiaga ne visada atskleidžia eksponuojamų kūriniu atsiradimo kontekstą, dažnu atveju neleidžia žiūrovui patirti erdvès pojūčio, kuris yra neatsiejamas nuo architektūros disciplinos. Kaip atsvarą tradicinems parodoms kuratoriai ịvardina ìvairias medijas jungiančias ir konceptualiomis priemonėmis žiūrovo vaizduotę bei mąstymą skatinančias šiuolaikines parodas, kurių užuomazgas galima aptikti jau XX a. pradžioje. Tuo metu architektai visame pasaulyje pradèjo ieškoti naujų architektūrinių sprendimų, galinčiu tenkinti atsiradusius socialinius poreikius. Nenuostabu, jog architektūros įtraukimo ị savo programas svarbą pradejo suvokti ir tuometiniai modernaus meno muziejai ${ }^{4}$, kurie siekè žiūrovui pristatyti jų laikotarpi geriausiai atspindinčias tendencijas. $\mathrm{XX}$ a. pr. modernių kultūros institucijų ekspozicijose jau buvo galima apčiuopti akivaizdžius architektūros prezentacijos supratimo pasikeitimus: imama vartoti instaliacijos sąvoka, leidžianti kalbèti apie erdvinius žiūrovo potyrius, pradedamos rengti architektūrinius procesus apibendrinančios ar apibrěžiančios parodos ir pan. Dar vienas architektūros ir urbanistinių parodų raidos poslinkio taškas gali būti sietinas su instituciniais pokyčiais muziejų ir galerijų veikloje $\mathrm{XX}$ a. 7-8 dešimtmečiuose. Šiuo laikotarpiu modernaus meno institucijos ima suvokti vizualios komunikacijos su žiūrovu, meno ir visuomenès santykio svarbą veikloje ir ima pabrèžti tai institucijų igyvendinamoje politikoje (Crimp 1993). Demesys pradedamas kreipti i ekspozicijos ryšį su įvairiais žiūrovais (profesionalais ir neprofesionalais), parodų lankytojams suteikiama galimybè patirti erdvinius pojūčius (pvz., pasivaikščioti po modelių vidų) (Hughes 2005: 30). Parodas pradeda lydèti katalogai, kuriuose apžvelgiamas politinis ir ideologinis architektų kūrybos kontekstas. Imama aktyviai diskutuoti architektūros definicijos, architektūros ribų klausimais. Pasitelkus žaidimo ir pažinimo praktikas paroda savaime tampa ir eksponatu, ir eksponavimo būdu (savo forma ir turiniu), riba tarp to, kas yra parodos architektūra, ir to, kas yra architektūra parodoje, nyksta.

Svarbūs šiuolaikinei architektūrai tampa parodose ir stambiose bienalèse kuriami manifestai, reiškinių analizè, žiūrovo įtraukimas ir jo įgyjamos patirtys. Architektas, kaip ir bet kuris kitas menininkas, nau-

\footnotetext{
4 Architektūrą pristatančias parodas pradèjo rengti tokios kultūros institucijos kaip Niujorke esantis Modernaus meno muziejus (MoMA), Paryžiaus modernaus meno galerija Galerie L'Effort Moderne, parodų rūmai Grand Palais, Amsterdamo Stedelijk muziejus.
}

doja panašias priemones ir praktikas idèjoms perteikti. Tai irodo ir Victionary sudaryta knyga „Kai menas susitinka erdvę/Kai erdvè susitinka meną" (When art meets space, when space meets art), iliustruojanti gausius menų sąveikos erdviniuose sprendimuose pavyzdžius, kuriuose nedaroma takoskyra tarp architektūros ir dizaino, teigiant, jog kai erdvès dizainas ir menas jungiami drauge, siekiant paveikti žiūrovą, sukuriami issimintiniausi kūriniai.

\section{Lietuvos atvejis}

Žvelgiant $\mathfrak{i}$ Lietuvos architektūros ir urbanistikos prezentacijos praktikas ir lyginant jas su pasaulinèmis tendencijomis, pirmiausiai reikètu atsižvelgti $\mathfrak{i}$ Lietuvos parodinio konteksto problematikai įtaką darančius veiksnius. Tenka konstatuoti, kad Lietuvoje architektūra yra suprantama pirmiausia kaip pastatų kūrimo amatas ir apie ją beveik nekalbama kultūros politikos kontekste. Galbūt todèl, kalbant apie architektūros reiškinių analizę, architektūrai nèra užtikrinamas pakankamas dèmesys nustatant politinius prioritetus, neskiriamas finansavimas žmogiškiesiems resursams tobulinti. Didelę itaką negausioms architektūros parodoms daro tai, jog Lietuvoje nèra institucijos, kuri užsiimtų architektūros edukacija visuomenèje ar architektūros prezentacijos veikla. Tenka pripažinti, kad yra didelis atotrūkis tarp architektų ir visuomenès.

Architektūrai pristatyti esamose negausiose parodose naudojamos tradicinès priemonès, kurios nèra pakankamos, kad užtikrintų neprofesionalaus žiūrovo i̊sitraukimą ị diskusiją su architektais, miesto reiškinių analizę. Architektūros parodų rengejų pastangos neduoda norimo rezultato ir dèl nepakankamo dèmesio edukacijai bei viešajai komunikacijai. Galų gale nedeklaruojama, kokio rezultato siekiama, parodos dažniausiai plokščios, trūkstant lěšų - virtualios, skirtos mažam profesionalų ir studentų būriui. Dažniausiai analizuojamas architektūros rezultatas, bet nesigilinama ị procesą ar atsiradimo kontekstą. Viena vertus, neturint reikiamų architektūros teorijos priemonių, teorinis diskursas arba kritinis kuravimas tampa neįmanomas. Kita vertus, parodos šiuo metu atlieka informacijos rinkimo, kaupimo ir sklaidos funkciją, kuri yra itin svarbi, nors ir nepakankama neturint architektūros muziejaus.

Dèl šių priežasčių Lietuvoje susidaro savotiškas vakuumas, kuris sukuria sąlygas labai specifiniam „lietuviškam“ kontekstui susidaryti - neegzistuojant oficialiai (politinei, institucinei ir kt.) pozicijai, atsiranda terpé alternatyvioms veikloms. Tokioje situacijoje architektūros parodos forma užleidžia vietą tarpdisci- 
plininio pobūdžio visuomeniniams, meniniams, socialiniams projektams, inicijuojamiems viešosiose miesto erdvèse ir ị architektūros diskusijas visuomenès narius įtraukiantiems įvairiomis priemonèmis (pilietinemis akcijomis, diskusijomis, meninemis interpretacijomis). Konceptualios ir daugiau diskusijų visuomeneje sulaukiančios architektūros prezentacijos formos yra viešosiose erdvèse igyvendinami tarpdisciplininio pobūdžio projektai (tiriančiosios praktikos). Tokiomis architektūrą pristatančiomis formomis auditorija yra pasiekiama įtraukiant visuomenę ị kūrybinị procesą, o kartu yra sudaromas pagrindas komunikacijai tarp architektų ir visuomenès užsimegzti. Lietuvoje tiriančiuju parodų tipui taip pat galima priskirti meninių parodų praktikas, kurioms būdinga gyvenamosios aplinkos, joje vykstančių architektūrinių ir socialinių procesų tematika. Jose netradicinėmis architektūros reprezentacijai, tačiau palankiai šiuolaikinių kuratorių vertinamomis formomis yra kontekstualiai ir konceptualiai atkreipiamas dèmesys ị architektūrinès aplinkos santykį su kasdieniniu gyvenimu ir jo kokybe, naudojamas netiketumo efektas.

Lietuvoje nèra specializuotos architektūros reprezentacija užsiimančios institucijos, todèl dalis architektūros ir urbanistikos discipliną nagrinèjančių projektų yra inicijuojami nedidelių visuomeninių organizacijų. Tai rodo, jog tokių projektų poreikis, taip pat ir visuomenès noras ịsitraukti $\mathfrak{i}$ architektūros diskursų diskusiją auga. Viena tokių iniciatyvų yra jau 27 metus su pertraukomis gyvuojantis architektūros studentų idejų konkursas Sikon. Konkursas, kurio forma transformuojasi ir yra jautri visuomeniniams pokyčiams, ilgainiui tapo kūrybinèmis dirbtuvemis, kurių pagrindiniai tikslai yra aktualumas, socialinis aktyvumas, veiksmas. Neretai kūrybinèms dirbtuvèms pasirenkamos probleminès Lietuvos vietos. Jose vèliau eksponuojami dirbtuvių rezultatai, ieškant santykio su supančia aplinka, stengiamasi ittraukti vietines bendruomenes, analizuojami teoriniai architektūros klausimai, provokuojamos diskusijos, rengiamos paskaitos. Konkursinis aspektas tampa vis labiau antraplanis, akcentuojant dirbtuvėse vykstantị dalinimąsi patirtimi, bendravimą ir bendradarbiavimą. Konkursas Sikon užima svarbią vietą architektūros kultūros vakuume, nes studentai imasi analizuoti aktualias temas ir definicijas, ieško alternatyvių eksponavimo formų.

Pirmoji Lietuvoje, atgavus nepriklausomybę, paroda „Žvilgsnis ị save“ (7 pav.), kuri nuo $2003 \mathrm{~m}$. buvo gana reikšminga užpildant parodinio diskurso trūkumą, ilgainiui perkelta ị internetą. Toks sprendimas, viena vertus, yra puiki galimybė nusistovejjusią plokščią parodos formą padaryti interaktyvią, prieinamą platesnei visuomenès daliai (su pristatomais darbais susipažinti gali visi besidomintys neatsitraukdami nuo kompiuterio), be to, mažina parodos rengimo sąnaudas. Kita vertus, virtuali erdvė gali tapti dar plokštesne parodos eksponavimo forma, nes ilgainiui ji tampa dviejų dimensijų grafikos darbų talpykla, dirbtine, suprantama ir iqdomia tik profesionalams ir parodos dalyviams.

Šiame diskurse verta paminèti ir kitą urbanistinị ir viešosios aplinkos diskursą akcentuojantị, taip pat ieškantị naujų visuomenès įtraukimo ị miesto erdvių klausimų sprendimą projektą KultFlux, kuris, inicijuotas grupės jaunų architektų ir meno kritikų, nuo 2008 m. yra igyvendinamas Vilniaus Neries krantineje ìsikūrusiame paviljone (KultFlux paviljonas, 8 pav.). KultFlux platformos programoje nemažas dèmesys skiriamas miesto socialinių, architektūrinių procesų analizei, pasitelkiant ịvairias formas - temines parodas, viešas diskusijas, kūrybines dirbtuves, kino programą.

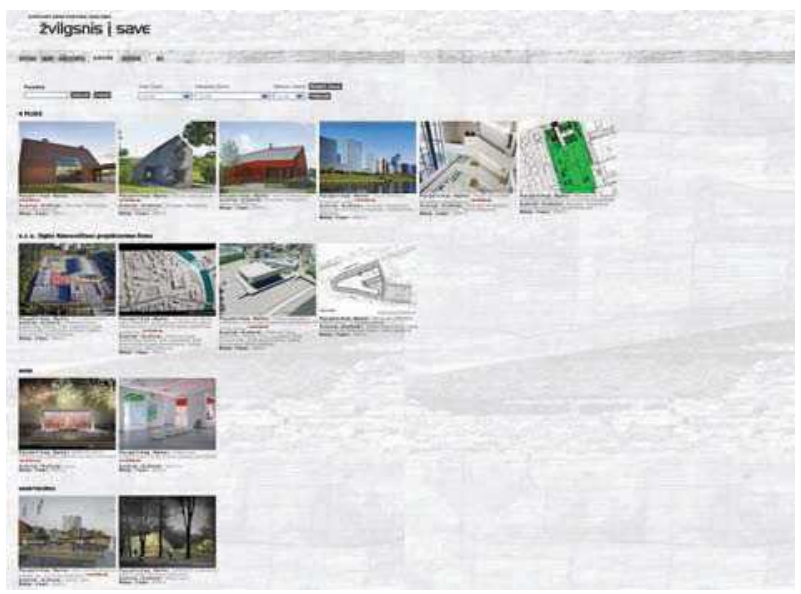

7 pav. Parodos „Žvilgsnis i save“ fragmentas internete (iš www.lietuvosarchitektura.lt)

Fig. 7. Fragment of on-line exhibition "Introspection"

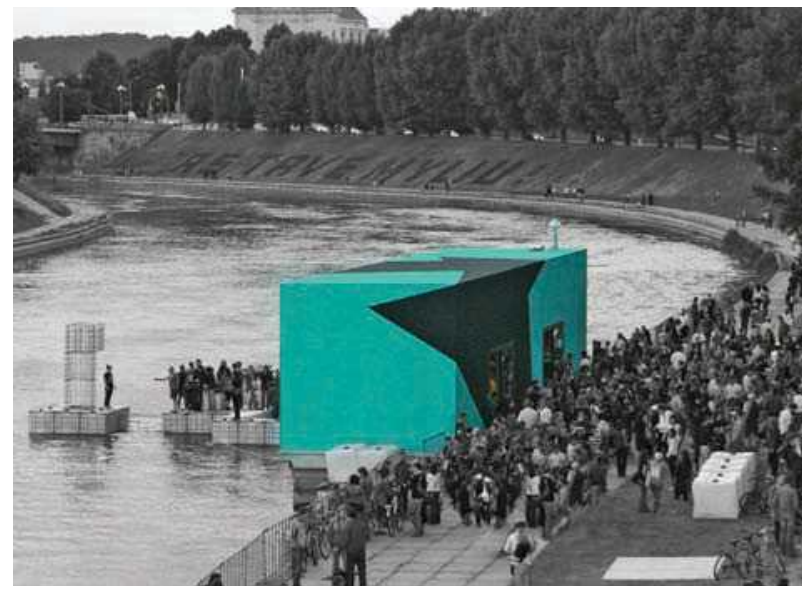

8 pav. KultFlux paviljonas, 2008 m., Astos Visminaitès fotografija

Fig. 8. Pavilion Kultflux, 2008, photo by Asta Visminaitè 
Bendruomenei įtraukti į miesto erdvių ir architektūros procesus čia pasitelkiamos meninès praktikos, kuriomis naudojamasi siekiant pritraukti plačiąją auditoriją. KultFlux atvejis yra įdomus ir tuo, jog programos renginiai vyksta paviljone, kurị kaip mediją palankiai vertina pasaulio architektūros parodų praktikai, nes paviljonas suteikia galimybę architektams igyvendinti 1:1 mastelio modeli. Paviljonas turetų atkreipti dèmesi i šiuo metu mažai išnaudojamas Neries upès krantines, taip pat tapti savotišku traukos objektu, sukurti priežastị ateiti i šalia upès esančias rekreacines zonas. Paviljonas funkciniu požiūriu yra laikinas statinys, kurio forma gali kisti, pritaikant jo erdvę skirtingoms koncepcijoms išreikšti. Be to, paviljono privalumas yra tas, jog lankytojų jis nèra asocijuojamas su kultūros institucija, kuri gali būti tapatinama su galios ar autoritariniu simboliu. Taigi, i ji galima pritraukti ne tik profesionalus, bet ir tokią publiką, kuri paprastai nesilanko architektūros parodose.

Dar viena alternatyvia architektūros ekspozicijos forma galima būtų ìvardinti Vilniaus miesto savivaldybès inicijuotą "Architektūros parko“ idèją. "Architektūros parkas" - tai projektas, kurio metu Vilniaus kvartalai palei Vilnios upę (nuo Užupio iki Belmonto) turètų tapti „prestižiniu sostinès kvartalu, pastatytu remiantis darnios pletros principais bei pagrịstu aukštųjų technologijų ir pažangių socialinių idèjų sąjunga“" (Architektūros parko... 2009: 1). Ši projektą koordinuojančios architektès, Vilniaus miesto savivaldybès atstovès R. Matonienès teigi$\mathrm{mu}$, ideja gimé apsilankius analogiškose Vokietijos ir Švedijos miestų architektūros parodose po atviru dangumi, tokiose kaip Interbau kvartale (kvartalas statytas 1952-1957 m., Berlyne), Emscher park kvartale (kvartalas statytas 1989-1999 m., Berlyne), Bo01 kvartale (2001 m., Malmeje). Visi minèti pavyzdžiai veikia kaip puikiai miesto atžvilgiu funkcionuojančios architektūros parodos po atviru dangumi. Lietuvoje "Architektūros parko“ projektas ịvertintas už tai, jog i jo koncepcijos kūrimą, planavimo procesus yra ịtraukiami ịvairių socialinių sluoksnių atstovai (nekilnojamo turto vystytojai, architektai, sociologai, kūrybinių industrijų specialistai, vietinès ir miesto bendruomenès) ir keliama vieša diskusija ne tik apie ateityje atsirasiantị kvartalą, bet ir pabrèžiama teritorijos istorine praeitis, architektūrinis-urbanistinis paveldas, analizuojamas teritorijos santykis su sostinès senamiesčiu. Nors projektas yra pradiniame rengimo etape, tačiau jau iki šiol ị kūrybinị procesą skirtingu sričiu specialistai ir visuomenè yra ịtraukiami skirtingais būdais. $2008 \mathrm{~m}$. buvo surengtos kūrybinès dirbtuvès, kuriose buvo diskutuojama ir ieškoma bendru sprendimų ir formuluojamos tolesnès kvartalo plètros galimybès (dirbtuvès gali būti prilyginamos laboratorijai, kuri sudaro prielaidas gyvenamosios aplinkos ir miesto planavimo diskursui atsirasti), buvo vykdoma visuomenès apklausa, kurios rezultatus vizualizavo architektų grupès. Reikia tikètis, kad igyvendinus toki projektą atvira lankytojui teritorija funkcionuotų kaip pavyzdinès architektūros parkas, taip pat leistų lankytojui patirti erdvinius pojūčius, būnant tarp natūralaus mastelio statinių.

\section{Paroda kaip architektūros laboratorija}

Kaip jau minèta tekste, architektūrinès ir meninès praktikos šiuolaikineje parodoje, kalbant tiek apie parodos tipą (tiriančioji, apibendrinančioji), tiek apie eksponavimo būdą (instaliacija, interaktyvumas), susiniveliuoja. Meninès praktikos yra pasitelkiamos architektūros ir urbanistikos klausimams visuomeneje diskutuoti, o architektūros parodos interaktyviais, kolaboraciniais ir erdviniais metodais gali labiau priminti meno kūrinị nei tradicinị architektūros pristatymą. Kai kalbama apie instaliaciją ar ịvairias medijas pasitelkiančius eksponavimo metodus, iš tiesų takoskyros tarp kūrinio ir jo eksponavimo būdo nebelieka. Tokios šiuolaikinès architektūrinès, meninès praktikos yra puiki niša teorinių diskursų bei praktinių galimybių analizei ir gali būti naudingos kaip architektūros laboratorija.

Architektūros laboratorijos pavyzdžiu galètų būti architektūriniai parodų sprendimai, kurie suteikia daug galimybiu visiems su paroda susijusiems asmenims: kuratorius čia gali programuoti teorinị, kritinị, edukacinį ar kitą diskursą; architektui tai yra galimybé 1:1 masteliu realizuoti utopines, eksperimentines idejjas, be to, jam yra suteikiama pakankamai didelè kūrybinè laisvé; žiūrovas tokioje instaliacijoje gali tiesiogiai patirti erdvę, kuri yra nekasdieniška. Parodos architektūroje naudojant instaliaciją žiūrovui suteikiama proga patirti erdvès pojūtị.

Vienu iš parodos architektūros atvejų Lietuvoje galima ịvardinti $2009 \mathrm{~m}$. Nacionalinèje dailès galerijoje vykusios parodos „Šaltojo karo metų modernizmas. Menas ir dizainas: 1945-1970" architektūros atsiradimo procesą (autoriai aexn architektai - T. Grunskis, L. Miceika, R. Šimatonyte, I. Cicènaitè ir J. Reklaitè). Iš Karališkojo Viktorijos ir Alberto muziejaus (Londone) atvežta paroda turèjo griežtą eksponatų skirstymą teminėmis dalimis. Lietuvoje architektams teko užduotis pritaikyti ekspozicinę erdvę šiai parodai Nacionalineje dailès galerijoje, o siūloma architektūra turèjo reflektuoti parodos koncepciją. Parodos architektūros autorių kolektyvas po nedidelių kūrybinių dirbtuvių pasiūlè kelis variantus, tematiškai aktualizuojančius parodoje 
aptariamo laikotarpio idejjas, iš kurių buvo patvirtinta žaidimo „laivais“" ekspozicijos strategija. Architektai tematinị eksponatų skirstymą igyvendino sukurdami erdvinę instaliaciją: skirtingo dydžio skirtingomis spalvomis „užkoduotos“ geometrinès erdvès - tarsi nedidelio masto paviljonai galerijos patalpose - skyrè parodos daliu ribas, leido žiūrovui laisvai rinktis judejimo krypti, be to, estetinèmis priemonèmis suteikè auditorijai galimybe pasijusti instaliacijos viduje, taip buvo simuliuojamas erdvès pojūtis. Architektūros instaliaciją analizuojančios ir jos formą savo veikloje praktikuojančios grupès Asymptote architektès Hani Rashid teigimu, „kadangi forma ir turinys instaliacijoje yra neatskiriami vienas nuo kito, galima sukurti tokias erdves, kuriomis bus peržengiamas didaktinis parodų aspektas" (Rashid 2001: 34). Šios parodos atveju architektų grupès pasiūlytas variantas ne tik išsprende organizatorių keliamus reikalavimus, bet ir leido kūrybinei grupei paeksperimentuoti igyvendinant architektūrines idèjas 1:1 masteliu, ịtraukè vartotoją per jutimines patirtis, o konceptualiai grịstas tūrių išdèstymas ekspozicijoje parodai suteikè pridètinès vertès ( 9 pav.).

Kita sritis, kur gali būti sèkmingai taikomas architektūros laboratorijos metodas, yra ịvairios tarpdisciplininès, ịtraukiančios praktikos. Viena iš jų, pateikiama kaip galimas pavyzdys, yra Vilniaus Gedimino technikos universitete, Architektūros fakultete vykdomas instaliacijos disciplinos kursas (vadovas A. Novickas), kuriame studentai dirbdami architektūros fakulteto pastatuose kuria erdvines instaliacijas. Taip studentai tiria erdvès parametrus, analizuoja ją ir pristato teorinius diskursus, ieško kokybinių parametrų ir juos interpretuoja, taip suvokia, jog meninès praktikos nèra intuityvios, greičiau jos yra racionalios ir skirtos problemoms analizuoti bei perteikti, provokuoti ir pan. Dirbdami konkrečioje vietoje jie turi galimybę dirbti su objektais 1:1 masteliu, susipažinti su meninèmis praktikomis, gryninti savo koncepcijas, bendradarbiauti tarpusavyje ir analizuoti vieni kitų darbus, šmaikščiai provokuoti fakulteto lankytojus (10 pav.).

Iš dalies architektūros laboratorija galima pavadinti ir kai kurias įvykusias šiuolaikinio meno parodas, kuriose sèkmingai bendradarbiavo menininkai bei architektai. Prie tokių skirtingas disciplinas jungiančių bei bendradarbiavimą tarp skirtingų sričių kūrèjų skatinančių projektų galima priskirti $2009 \mathrm{~m}$. Šiuolaikinio meno centre pristatytas X Baltijos tarptautinio meno trienales „Miesto istorijos“ parodas. Diskursyviai mieste vykstančius procesus, pokyčius bei pastebèjimus apie viešąsias erdves menininkų bei architektų akimis pristatè trienalès paroda Vilnius COOP (kuratorès Vera Lauf ir Ūla Tornau). Ilgą laiką miesto centre nenaudojamame pastate eksponuojama paroda ne tik pasiūlè naują funkcinę panaudą buvusiai visuomeninei erdvei, bet

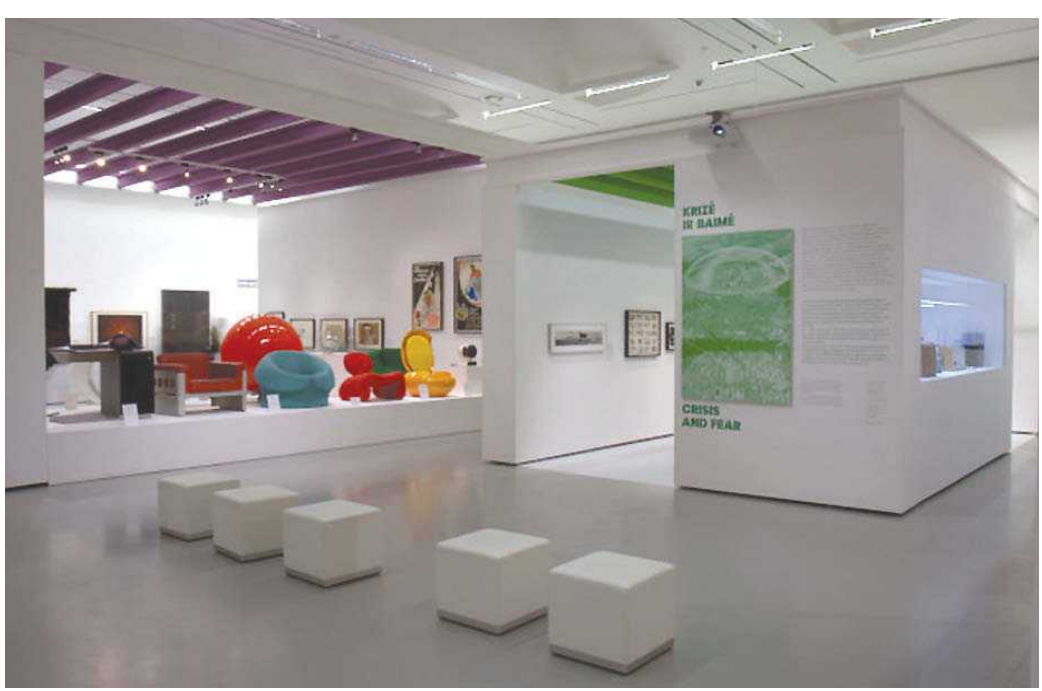

9 pav. Parodos „Šaltojo karo metu modernizmas. Menas ir dizainas: 1945-1970" fragmentas, 2009 m., G. Ilgūno fotografija

Fig. 9. Fragment of exhibition "Cold-war modern art and design: 1945-1970", 2009, photo by G. Ilgūnas

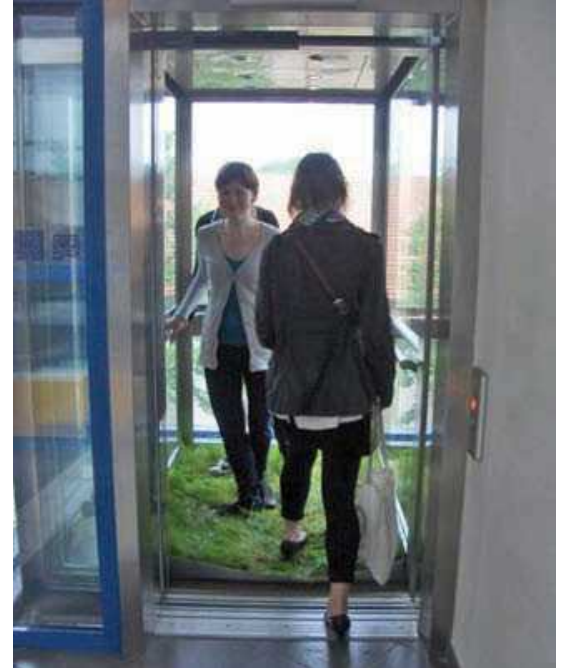

10 pav. A. Dovydavičiūtès instaliacija "Liftas", 2010 m., autorès fotografija

Fig. 10. Installation by A. Dovydavičiūtè "Elevator", 2010, author's photo

\footnotetext{
Žaisdami „laivais“ žaidejjai $10 \times 10$ langelių teritorijoje nusibrèžia savo „laivų“ ribas ir bando atspèti priešininko teritorijoje užkoduotus „laivus“, šios parodos atveju žaidimas pasitelktas kaip informacinio karo, konkurencijos metafora.
} 
ir aktualizavo pastato atsiradimo kontekstą istoriniu bei socialiniu aspektais, per šią problematiką atskleidè bendruomeninius ir privatizavimo sankirtos procesus mieste, pristatè skirtingų menininkų atliktus tyrimus Vilniaus mieste. Be to, parodos metu auditorijai taip pat buvo pasiūlyta dalyvauti kino peržiūrose, sociologu bei menininku prezentacijose, tad savotiškai buvo sukurta ir platforma diskusijai, suteikiančiai galimybę parodos lankytojui išgirsti skirtingų sričių specialistus bei išsakyti savo nuomonę.

Kitas šio pranešimo kontekste vertas dèmesio trienalès parodos „Juodos gulbès, tikros istorijos ir privačios tiesos" (kuratoriai Ann Demester ir Kęstutis Kuizinas, 2009 m.) elementas yra architekto Valdo Ozarinsko pasiūlyta parodos Šiuolaikinio meno centre (ŠMC) architektūra, kuri instaliacijos forma sprende parodos eksponatų išdèstymo funkciją. V. Ozarinskas skirtingoms miesto istorijoms sujungti sukonstravo penktadaliu mažesnį ŠMC pastato modelį, erdvèje atkartojantị originalių salių sienų ribas (Ekskursija su kuratoriais... 2010: 22). Igyvendindamas darniai i ekspozicijos koncepciją įsiliejantị didelio masto pastato maketą, architektas turejo galimybę realizuoti savo menines ambicijas, kartu pasiūlyti žiūrovui „kitaip“ patirti ŠMC parodų erdves.

Parodinès praktikos, kuriose pasitelkiamos šiuolaikiniame mene naudojamos strategijos ir medijos, rodo, jog ribos tarp architektūros parodoje bei parodos architektūros ar tarp architektūrinès ir meninès praktikos pamažu nyksta, o tarpdiscipliniškumas leidžia atskleisti tokius architektūros aspektus, kurie palieka vietos diskusijai ir galimybę permąstyti kintančią architektūros definiciją.

\section{Apibendrinimas}

Pastaruoju metu esančios pasaulinès parodinès praktikos bei teorinis jų diskursas rodo, jog parodose nebeužtenka pateikti vizualizacijas ir modelius, kuriuos gali pristatyti kiekviena architektūros studija, sèkmingos yra laikomos tokios parodos, kuriose, sujungus įvairias medijas, žiūrovas yra paskatinamas gilintis ị ekspozicijose aptariamų objektų atsiradimo kontekstą, istorinę miesto praeiti, socialinius aspektus. Konceptualioms erdvés planavimo idèjoms perteikti pasitelkiamos jutimiškai paveikios priemonès: instaliacija, kuria galima vaikščioti ir fiziškai patirti erdvę, provokaciniai, erdviniai, interaktyvūs metodai, kuriais siekiama įtraukti žiūrovą, suteikti jam naujų patirčių, žiniu, provokuoti.

Straipsnyje teigiama, jog menų ir architektūros sąveika šiuolaikinèse architektūrinèse bei meninèse praktikose gali būti puikia žaidimų aikštele tiek menininkams, tiek architektams, nes tai:

- galimybe tyrinèti masteliu 1:1;

- terpè igyvendinti architektūrines utopijas;

- galimybė analizuoti architektūros reiškinius;

- erdvè diskusijai;

- architektūros konteksto kaita;

- galimybe įtraukti vartotoją;

- tarpdalykinès patirtys ir kolaboracijos galimybès;

- architektūros ir meno diskurso išplètimas;

- alternatyvios reiškinių analizės ir eksponavimo formos.

Išnagrinejjus Lietuvos parodų architektūros ir architektūros eksponavimo parodose pavyzdžius tiek parodos tipo, tiek eksponavimo būdo požiūriu, galima teigti, kad Lietuvoje vis dar vyrauja tradicinèmis formomis architektūrą pristatančios parodos. Konvencines parodos formas Lietuvoje keičia tarpdisciplininio pobūdžio visuomeniniai, meniniai bei socialiniai projektai, savotiškai užpildantys oficialiosios pozicijos spragą, taip pat suteikiantys daugiau galimybių architektūros laboratorijai atsirasti. Architektūros laboratoriją galima laikyti menų sąveikos architektūroje pavyzdžiu, kai tarpdiscipliniškumo metodas taikomas architektūrinèms ir meninėms praktikoms papildant ir paịvairinant vienai kitą, tuomet riba tarp to, kas yra architektūra ir kas yra jos eksponavimas, išnyksta.

\section{Literatūra}

Architektūros parko kūrybinès dirbtuvès. 2009. Vilnius: Vilniaus $m$. savivaldybè.

Baužienè, M. 2008. Neatšvęstas Architektūros muziejaus keturiasdešimtmetis, Kultūros barai 9: 61-63.

Crimp, D. 1993. On the museums ruins. MIT press.

Curating Architecture. Seminars at Goldsmiths College [interaktyvus]. Seminar 3, 2007-09-13 [žiūrèta 2007 m. lapkričio 7 d.]. Prieiga per internetą: <http://old.gold.ac.uk/art/ curating-architecture//seminar03.html $>$.

Dernie, D. 2006. Exhibition design. Laurence King Publishing. Kassel

Ekskursija su kuratoriais Ann Demeester ir Kęstučiu Kuizinu po parodą "Juodos gulbės, tikros istorijos ir privačios tiesos", iš Vilniaus istoriju knyga. Tariama X Baltijos trienalès antologija. 2010. Vilnius: ŠMC, 20-63.

Hughes, L. 2005. Do we need new spaces for exhibiting contemporary art?, Journal of Visual Art Practice 4 (1): 29-38. doi:10.1386/jvap.4.1.29/1

Feireiss, K. 2001. Introduction: It's not about art, in Art of Architecture Exhibitions. Kristin Fereiss (Ed.). Rotterdam: NAi publishers, 8-15.

Lubytè, E. 1997. Tylusis modernizmas. Parodos katalogas. Vilnius: Tyto alba.

McLuhan, M. 2003. Kaip suprasti medijas: Žmogaus tęsiniai. Vilnius: Baltos lankos. 
Miesto žymèjimas. Pažymètos teritorijos. 2005. Sud. R. Goštautienė, L. Jablonskienè. Vilnius: Tyto Alba, 241-245.

Migayrou, F. 2005. Exhibiting architecture: the Praxis questionnaire for architectural curators. Praxis 7: 113-115.

Rambow, R. 2004. Exhibiting architecture: The Visitor's Perspective, in B. Martens, A. G. Keul (Eds.) Evaluation in Progress - Strategies for Environmental Research and Implementation. IAPS 18 Conference Proceedings, 2004 07 7-9, CD-Rom. ISBN 3-85437-263-9.

Rashid, H. 2001. Installing Space, in The Art of Architecture Exhibitions. Kristin Fereiss (Ed.). Rotterdam: NAi publishers, 34-42.

Reklaitè, J. 2010. Apie architektūra paraštèse. Paroda „Našlaičiai“ Nacionalineje dailès galerijoje [interaktyvus], [žiūrèta $2010 \mathrm{~m}$. gruodžio $3 \mathrm{~d}$.]. Prieiga per internetą: $<$ http://www.7md.lt/lt/2010-12-03/miesto_veidas/apie_ architektura_parastese.html>.

When art meets space, when space meets art. Spatial, structural and Graphical Design for Event and Exhibition. 2007. Victionary (ed.).

\section{ARCHITECTURE AT EXHIBITIONS (LITHUANIAN CASE)}

\section{A. Visminaité, J. Reklaite்}

Abstract. The title of this paper reveals an ambiguity of the issue analysed and ambivalent role of architecture at exhibitions: architecture here can be perceived as an object or topic tackled within exhibition (exhibition of architecture) as well as means to form the space of exposition (architecture of exhibition). The paper analyses different implications of architecture at exhibition and will try to demonstrate that terms of interdisciplinarity and collaboration can be introduced while talking about presentation of architecture and its context. Also, the transformations of relationship between an object displayed and the way it has been exhibited are discussed. In this paper the Lithuanian context of exhibitions is discussed through the scale of types of exhibitions, levels of displays and the collaboration that emerges from them. To examine the problematic nature of double-edged perception of architecture, three types of exhibitions are defined in the paper - documenting, researching and summarizing exhibition practices which differ in the methods and aims of their analysis and curatorial praxis used. Also, for the analysis of architecture of exhibitions (or a display) three levels have been characterized $-2 \mathrm{D}, 3 \mathrm{D}$ and $4 \mathrm{D}$; apart from the technical part they are installed at exhibitions, they differ in the level the audience is involved and in the level the information can be interpreted.

Keywords: architecture as media, exhibition as a lab, culture of architecture, transformation, identity, concept of architecture/ exhibition, collaboration.

\section{ASTA VISMINAITE்}

Cultural platform "KultFlux", Antakalnio g. 88-15, 10204 Vilnius, Lithuania. E-mail: asta.visminaite@gmail.com

Projects: co-founder and curator of cultural platform by the river Neris "KultFlux" (urbanism, public design, visual arts). Research interests: architectural curating practices, representation of architecture in the context of exhibitions, public and urban design.

\section{JULIJA REKLAITE்}

Faculty of Architecture, Vilnius Gediminas Technical University, Pylimo g. 26/Traku g 1, 01132 Vilnius, Lithuania

E-mail: julija.reklaite@gmail.com

Publications: author and co-author of 3 research papers. Projects: architect or designer of around 20 exhibitions, cocurator of architecture discussion platform based in Vilnius. Research interests: the challenges of architecture representation, collaboration in contemporary practices, modernistic heritage and identity questions under the social change. 